\title{
PENGARUH MODEL PEMBELAJARAN PBL BERBANTUAN MEDIA GAMBAR TERHADAP HASIL BELAJAR IPA SISWA KELAS III SD
}

\author{
Ayu Ade Anjelina Putri ${ }^{1}$, Ign. Wayan Swatra ${ }^{2}$, I Made Tegeh ${ }^{3}$ \\ ${ }^{1}$ Jurusan PGSD, ${ }^{2,3}$ Jurusan TP, FIP \\ Universitas Pendidikan Ganesha \\ Singaraja, Indonesia \\ e-mail: ayuadep@yahoo.co.id ${ }^{1}$, wayansuwatra@yahoo.co.id ${ }^{2}$, \\ im-tegeh@undiksha.ac.id ${ }^{3}$
}

\begin{abstract}
Abstrak
Penelitian ini bertujuan untuk mengetahui perbedaan yang signifikan hasil belajar IPA antara siswa yang menggunakan model pembelajaran Problem Based Learning dan siswa yang tidak menggnakan model pembelajaran Problem Based Learnig pada siswa kelas III SD Gugus VI Kecamatan Sawan Tahun Pelajaran 2017/2018.Jenis penelitian ini adalah penelitian eksperimen semu. Desain penelitian ini yaitu Non-equevalent post-test only control group desaint.Populasi penelitian ini adalah seluruh siswa kelas III SD Gugus VI Kecamatan Sawan yang berjumlah 164 siswa. Sampel penelitian ini yaitu kelas III SDN 1 Kerobokan yang berjumlah 18 orang dan siswa kelas III SDN 4 Sangsit yang berjumlah 23 orang.Metode pengumpulan data dilakukan dengan metode tes yaitu dengan instrumen tes objektif (pilihan ganda). Data yang diperoleh dianalisis dengan menggunakan teknik analisis statistik deskriptif dan teknik analisis statistik inferensial yaitu uji-t. Hasil penelitian ini menunjukan bahwa terdapat perbedaan yang signifikan hasil belajar IPA antara siswa yang menggunakan model pembelajaran Problem Based Learning dan siswa yang tidak menggunakan model pembelajaran Problem Based learning dengan $t_{\text {hitung }}=4,75>t_{\text {tabel }}=2,042$. Berdasarkan hasil analisis data model pembelajaran Problem Based Learning berpengaruh terhadap hasil belajar IPA. Hal ini dapat dilihat dari skor rata-rata siswa yang menggunakan model pembelajaran Problem Based learning yaitu 16,52 dan skor rata-rata siswa kelompok kontrolyaitu 11,77. Jadi terdapat perbedaan yang signifikan hasil belajar antara siswa yang dibelajarkan model pembelajaran Problem Based Learning dan siswa yang tidak dibelajarkan dengan menggunakan model pembelajaran Problem Based Learning pada siswa kelas III SD Gugus VI Kecamatan Sawan Tahun Pelajaran 2017/2018.
\end{abstract}

Kata kunci:Hasil Belajar, IPA, PBL

\begin{abstract}
The purpose of this research is to know the significant difference of science learning outcomes between the students who use problem based learning method and the students who don't use the method to the 3rd grade primary students of cluster VI, sawan distric in academic year 2017/2018. This kind of research is quasi-experimental research. The design of the research is non equevalent post test only control group design. The population of this research are all of 3rd grade primary students, cluster VI, sawan distric. There are 164 students. The samples of this research are the 3rd grade primary students of SDN 1 kerobokan. There are 18 students as samples and 23 of the 3rd grade students of SDn 4 sangsit. The method of collecting data by "test" metod, namely instrument objective test (multiple choices). The collected data is analyzed by using analysis statistic descriptive and analysis statistic imperencial uji -t. The result of this result show that there are significant difference from the outcomes of science learning between the students who use problem based method and the students who dont use the method with $t$ itung 4.75 ttable 2.042. Based on the problem based learning method, it influences the outcomes of learning science. This can be seen from the average score that use problem based learning method: 16.52 and the average score of the control group : 11.72. So there are significant difference from the students who use problem based method and the students who dont use the method to the 3rd grade students of SD gugus VI sawan distric in academic year 2017/2018.
\end{abstract}

Keywords: learning result(outcomes), science, PBL 


\section{PENDAHULUAN}

Pendidikan diselenggarakan dengan melibatkan guru sebagai pengajar serta siswa sebagai peserta didik. Guru merupakan sosok yang tiada henti memberikan kasih sayang kepada peserta didiknya. Tanpa guru belum tentu siswa dapat membaca, menggambar, menghitung dan menulis, serta minat dan bakat siswa tidakakan dapat erkembang dengan baik tanpa bantuan dari seorang guru.Setiap anak memiliki tingkat perkembangan yang berbedabeda.Pendidikan merupakan halyang penting untuk menciptakan manusia yang mamapu menghadapi tantangan kedepannya.Pendidikan guna juga berguna bagi manusia untuk mengembangkan potensi kecerdasan serta bakat yang dimiliki oleh seseorang menjadi sebuah prestasi.

Pendidikan sangat berkaitan dengan pembelajaran. Menurut Undang-undang Republik Indonesia No. 20 Tahun 2003 tentang sistem pendidikan nasional menyatakan bahwa "pendidikan adalah usaha sadar dan terencana untuk mewujudkan suasana belajar dan proses pembelajaran agar peserta didik secara aktif mengembangkanpotensi dirinya untuk memiliki kekuatan spiritual, keagamaan, pengendalian diri, kepribadian, kecerdasan, akhlak mulia, serta keterampilan yang diperlukan dirinya masyarakat, bangsa dan negara.

Berdasarkan observasi di SD Gugus VI Kecamatan Sawan telah terjadi kesenjangan antara harapan dan kenyataan dalam mata pelajaran IPA yang sebagian besar rata-rata nilai IPA siswa masih di di bawah KKM.Salah satu penyebabnya karena guru cenderung sering menggunakan pembelajaran konvensional tanpa menggunakan model. Guru yang baik dan professional biasanya dalam mengajar akan menggunakan model pembelajaran tertentu yang diyakini akan menjadikan pembelajaran lebih menarik dan terarah. Siswa juga tidak jarang cepat merasa bosan karena kurangnya interaksi yang melibatkan siswa secara langsung, kurangnya keterlibatan siswa dalam pembelajaran juga mengakibatkan siswa tidak dapat mengembangkan pengetahuannya.

Untuk mengatasi persoalan tersebut diperlukan inovasi guru untuk mengemas pembelajaran IPA.Salah satu inovasi yang tepat untuk mengatasi masalah tersebut, yaitu dengan menggunakan model pembelajaran yang dapat meningkatakan hasil belajar IPA siswa. Model pembelajaran adalah bentuk pembelajaran yang tergambar dalam proses pembelajaran yang disajikan secara khas oleh guru di kelas (Marhaeni, 2013:48). Model pembelajaran merupakan sebuah prosedur yang sistematis dalam mengorganisasikan pengalaman belajar untuk mencapai tujuan belajar (Kurniasih dan Sani, 2016: 18). Model yang cocok digunakan sebagai inovasi untuk meningkatkan hasil belajar IPA siswa yaitu dengan menggunakan model Problem Based Learning (PBL).

Shoimin (2014:129) menyatakan bahwa "model pembelajaran Problem Based Learning ini melatih dan mengembangkan kemampuan untuk menyelesaikan masalah yang berorientasi pada masalah autentik dari kehidupan aktual siswa, untuk merangsang kemampuan berfikir tingkat tinggi siswa". Model pembelajaran Problem Based Learning melatih siswa dalam berfikir untuk memecahkan suatu permasalahan. Model pembelajaran Problem Based Learning mampu memberikan siswa keleluasaan dalam belajar dan mengembangkan pengetahuan pemecahan masalah.Marhaeni (2013:137) menyatakan bahwa "Problem Based Learning adalah model pembelajaran yang berlandaskan paham konstruktivistik yang melibatkan peserta didik dalam belajar dan pemecahan masalah".Di dalam memperoleh infomasi dan mengembangkan pengetahuan tentang topik-topik, peserta didik belajar bagaimana menyusun kerangka masalah, mengumpulkan dan menganalisis, menyusun fakta, dan pendapat mengenai suatu masalah, bekerja secara kelompok maupun individu dalam pemecahan masalah.

Duch (dalam Shoimin 2014:130) menyatakan bahwa Problem Based Learning adalah model pembelajaran yang bercirikan adanya permasalahan nyata sebagai konteks untuk para peserta didik belajar berfikir kritis dan keterampilan memecahkan masalah serta memperoleh pengetahuan. Min Liu (dalam Shoimin 2014:130) karakteristik model pembelajaran Problem Based Learning, yaitu: a) Learning is student-centered Proses pembelajaran dalam Problem Based Learning lebih menitikberatkan kepada siswa sebagai orang belajar. Oleh karena itu, Problem Based Learning didukung juga oleh teori kontruktivisme dimana siswa di dorong untuk dapat mengembangkan pengetahuannya sendiri. b) Antbentic problems form the organizing 
focus for learning Masalah yang disajikan kepada siswa adalah masalah yang otentik sehingga siswa mampu dengan mudah memahami masalah tersebut serta dapat menerapkannya dalam kehidupan profesionalnya nanti. c) New information is acquired through self-directed learnig Dalam proses pemecahan masalah mungkin saja siswa belum mengetahui dan memahami semua pengetahuan prasyaratnya sehingga siswa berusaha untuk mencari sendiri melalui sumbernya, baik dari buku atau informasi yang lainnya. d) Learning occur in small group Agar terjadi interaksi ilmiah dan tukar pemikiran dalam usaha membangun pengetahuan secara kolaboratif, Problem Based Learning dilaksnakan dalam kelompok kecil. Kelompok yang dibuat menuntut pembagian tugas yang jelas dan penerapan tujuan yang jelas. e) Teacher act as facilitator Pada pelaksanaan Problem Based Learning, guru hanya berperan sebagai fasilitator, meskipun begitu guru harus selalu memantau perkembangan aktivitas siswa dan mendorong mereka agar mencapai target yang hendak diacapai.

Kelebihan dan KekuranganModel Pembelajaran Problem Based learning Shoimin (2014: 132) menyatakan kelebihan model pembelajaran Problem Based learning yaitu: 1) siswa didorong untuk memiliki kemampua memecahkan masalah dalam situasi nyata, 2) siswa memiliki kemampuan membangun pengetahuannya sendiri melalui aktivitas belajar, 3) pembelajaran berfokus pada masalah isehingga materi yang tidak ada hubungannnya tidak perludipelajari oleh siswa. Hal ini mengurangi beban siswa menghafal atau menyimpan informasi, 4) terjadi aktifitas ilmiah pada siswa melalui kerja kelompok, 5) siswa terbiasa menggunakan sumber-sumber pengetahuan baik ari perpustakaan, internet, wawancara, dan observasi, 6) siswa memiiki kemampuan menilai kemmpuan belajarnya sendiri, 7) siswa memiliki kemampuan untuk melakukan komunikasi ilmiah dalam kegiatan diskusi atau presentasi hasil pekerjaan mereka, 8) kesulitan belajar siswa secara individual dapat diatasi melaluikerja kelompok dalam bentuk peer teaching.

Kekurangan dari model pembelajaran Problem Based learning yaitu: 1) tidak dapat diterapkan untuk setiap mata pelajaran, ada bagian guru beerperan aktif dalam menyajikan materi, model ini lebih cocok digunakan pada pelajaranyang menuntu kemampuan tertentu yang kaitanya dengan pemecahan masalah, 2) dalam satu kelas memiliki tingkat keragaman siswa yang tinggi sehingga akan kesulitan dlam pembagian tugas.

Model pembelajaran PBL adalah suatu model pembelajaran yang pelaksanaannya dimulai dari menjelaskan tujuan pembelajaran serta mendorong peserta didik terlibat dalam kegiatan pemecahan masalah, masalah tersebut nantinya akan didiskusikan oleh siswa, kemudian dipresentasikan dan diakhir kegiatan, guru membantu peserta didik untuk merefleksikan materi pembelajaran. Seorang guru ketika menyampaikan materi pelajaran perlu menekankan pokok bahasan agar mempermudah siswa dalam memahami materi.Dalam hal ini guru perlu melibatkan media pembelajaran agar siswa tertarik dan mampu memahami pokok bahasan dengan mudah misalnya menggunakan media pembelajaran berupa gambar.

Rusnadi (dalam Laksana 2016) menyatakan bahwa "pelajaran IPA merupakan salah satu mata pelajaran yang penting ditanamkan pada anak didik, karena melalui pembelajaran IPA, siswa mampu bersikap ilmiah dalam memecahkan masalah-masalah yang dihadapi.Pendidikan IPA diharapkan mampu menjadi wahana siswa agar mampu mempelajari diri sendiri dan alam serta mampu memecahkan masalah nyata dalam kehidupan sehari-hari.

Sains atau IPA adalah usaha manusia dalam memahami alam semesta melalui pengamatan yang tepat pada sasaran, serta menggunakan prosedur, yang dijelaskan dengan penalaran sehingga mendapatkan suatu kesimpulan. Susanto (2013:167) menyatakan bahwa "Hakikat pembelajaran sains yang didefinisikan sebagai ilmu tentang alam yang dalam Bahasa Indonesia disebut dengan ilmu pengetahuan alam, yang diklasifikasikan menjadi 3 bagian yaitu: ilmu pengetahuan alam sebagai produk, proses, dan sikap.

Sikap dalam pembelajaran IPA yang dimaksud ialah sikap ilmiah.Dengan pembelajaran IPA di sekolah dasar diharapkan dapat menumbuhkan sikap ilmiah seperti seorang ilmuwan. Adapun jenis-jenis sikap yang dimaksud, yaitu: sikap ingin tahu siswa, percaya diri, jujur, tidak tergesagesa, dan Objektif terhadap fakta. IImu pengetahuan alam sebagai produk yaitu kumpulan hasil penelitian yang telah ilmuwan lakukan dan sudah membentuk konsep yang telah dikaji sebagai kegiatan empiris dan analitis. Bentuk IPA sebagai produk antara lain: fakta-fakta, prinsip, 
hukum, dan teori-teori IPA. IImu pengetahuan sebagai proses yaitu menggali dan memahami pengetahuan tentang alam serta kumpulan fakta dan konsep, maka IPA membutuhkan proses dalam menemukan fakta dan teori. IImu pengetahuan alam sebagai sikap. Sulistyorini (dalam Susanto 2013:169) menyatakan bahwa, ada sembilan aspek yang dikembangkan dalam pembelajaran sains, yaitu: sikap ingin tahu, ingin mendapat sesuatu yang baru, sikap kerja sama, tidak putus asa, tidak berprasangka, mawas diri, bertanggung jawab, berfikir bebas, dan kedisiplinan diri.

Jadi IPA adalah ilmu yang penting dalam kehidupan manusia, sehingga IPA mulai dibelajarkan sejak anak berada di sekolah dasar.Sikap ilmiah anak dapat berkembang melalui kegiatan-kegiatan pembelajaran IPA pada saat melakukan diskusi, percobaan, simulasi, dan kegiatan proyek dilapangan.Perkembangan sikap ilmiah siswa dibentuk berdasarkan keterampilan-keterampilan yang berbeda berdasarkan tingkat kognitif siswa.

Alasan IPA diajarkan di sekolah dasar digolongkan menjadi empat golongan yakni: a) IPA bermanfaat bagi suatu bangsa, kiranya tidak perlu dipersoalkan panjang lebar. Kesejahteraan materiil suatu bangsa banyak sekali tergantung pada kemampuan bangsa itu dalam bidang IPA, sebab IPA merupakan dasar teknologi, sering disebut-sebut sebagai tulang punggung pembangunan. Pengetahuan dasar untuk teknologi adalah tanpa dasar yang cukup luas mengenai berbagai gejala alam, b) bila diajarkan IPA menurut cara yang tepat, maka IPA merupakan suatu mata pelajaran yang memberikan kesempatan untuk berfikir kritis, misalnya IPA diajarkan dengan mengikuti metode menemukan sendiri. Anak diminta untuk mencari dan menyelidiki hal ini, c) bila IPA diajarkan melalui percobaan-percobaan yang dilakukan sendiri oleh anak, maka IPA bukan merupakan mata pelajaran yang bersifat hapalan saja, d) mata pelajaran ini mempunyai niai-nilai pendidikan yaitu mempunyai potensi yang dapat membentuk kepribadian anak secara keseluruhan (Samatowa, 2010).

Nawawi (dalam Susanto, 2013: 5) menyatakan bahwa "hasil belajar dapat diartikan sebagai tingkat keberhasilan siswa dalam mempelajari materi pelajaran di sekolah yang dinyatakan dalam skor yang di peroleh dari hasil tes mengenai sejumlah materi pelajaran tertentu".Sama seperti yang dinyatakan oleh Sudjana (dalam Yupriyanti, 2015) bahwa "hasil belajar merupakan kemampuan-kemampuan yang dimiliki siswa setelah ia menerima pengalaman".

Berdasarkan uraian diatas maka dapat ditarik kesimpulan bahwa hasil belajar adalah nilai atau point yang didapatkan oleh siswa melalui tes materi pelajaran.Tes yang diberikan setelah siswa mendapatkan pembelajaran yang dirancang oleh guru.Secara sederhana hasil belajar siswa dapat diartikan sebagai kemampuan siswa yang dapat diperoleh setelah melalui tahapan belajar karena belajar itu sendiri adalah bentuk usaha seseorang dalam memperoleh perubahan perilaku yang relative menetap.

Hasil belajar siswa dipengaruhi oleh faktor internal yaitu:1) Faktor fisiologis atau jasmani individu baik bersifat bawaan maupun yang di peroleh dari melihat, mendengar, struktur tubuh, cacat tubuh, dan sebagainya.2) Faktor psiologis baik yang bersifat bawaan maupun keturunan.3)Faktor kematangan baik fisik maupun psikis. Sedangkan yang tergolong faktor eksternal yaitu: 1) Faktor social (keluarga, sekolah, masyarakat). 2) Faktor budaya ( adat istiadat, ilmu pengetahuan dan tenologi, kesenian) 3) Faktor lingkungan (fasilitas rumah, fasilitas belajar, iklim).4) Faktor spiritual (keagamaan) (Ruhimat, 2013:140).

Faktor-faktor tersebut saling berinteraksi secara langsung atau tidak langsung dalam mempengaruhi hasil belajar siswa. Telah diuraikan diatas bahwa hasil belajar terdiri dari ranah kognitif, afektif dan psikomotor.Dalam hal ini peneliti meneliti khusus hasil belajar ranah kognitif siswa.

Menurut Sadiman (dalam Sukariyasa, 2014) media merupakan "perantara atau pengantar pesan dari pengirim ke penerima pesan".Menurut Sadiman (Riastini, 2016:78) menyatakan bahwa "media adalah segala sesuatu yang dapat berguna sebagai penyalur pesan dari guru ke siswa". Menurut Susanti (2013) bahwa "media pembelajaran berguna untuk mengatasi keragaman latar belakang siswa sehingga menimbulkan persepsi yang sama". Media Pembelajaran merupakan segala bentuk perangsang dan alat yang disediakan guru 
untuk mendorong siswa belajar secara cepat, tepat, mudah, benar dan tidak terjadinya verbalisme (Hanafiah dan Suhana,2009:59).

Adapun manfaat media pembelajaran menurut Sudjana dan Rifai (dalam Wuryandari, 2011:44) yaitu, a) Pengajaran akan lebih menarik perhatian siswa sehingga dapat menumbuhkan motivasi belajar, b) Bahan pengajaran akan lebih jelas maknanya sehingga dapat lebih mudah dipahami oleh para siswa dan memungkinkan siswa menguasai tujuan pengajaran dengan baik, c) Metode mengajar akan lebih bervariasi, tidak semata-mata komunikasi verbal melalui penuturan kata-kata oleh guru, sehingga siswa tidak bosan dan guru juga tidak kehabisan tenaga, apalagi guru mengajar tiap jam pelajaran. Hal ini sangat mendukung untuk digunakan guru di sekolah dasar mengingat keberadaannya sebagai guru kelas yang mengajar secara terus-menerus, d) Siswa lebih banyak melakukan kegiatan belajar, sebab tidak hanya mendengar uraian guru tetapi juga aktifitas lain seperti mengamati, melakukan, mendemostrasikan, dan lain-lain. Oleh karena itu media pengajaran yang dibuat guru hendaknya membuka kesempatan kepada siswa untuk ikut serta aktif dalam pemanfaatannya.

Rohani (dalam Musfiqon,2012:73) menyatakan bahwa media gambar adalah media yang merupakan reproduksi asli dalam dua dimensi, yang berupa foto atau lukisan. Tujuan utama penampilan beberapa jenis gambar adalah "untuk menvisualisasikan konsep yang ingin di sampaikan” Arsyad (dalam Musfiqon,2012:73).

Beberapa kelebihan media gambar menurut Musfiqon (2012) adalah a) sifatnya konkret karena gambar mampu menunjukan poko permasalahan dibandingkan dengan kata-kata verbal, b) gambar dapat mengatasi ruang dan waktu. Tidak semua benda, objek atau peristiwa dapat dibawa ke kelas, dan tidak selalu bisa dibawa ke objek/peristiwa tersebut.Gambar dapat mengatasi hal tersebut. Peristiwa-peristiwa yang terjadi di masa lampau, kemarin atau bahkan semenit yang lalu kadang tidak dapat kita lihat seperti apa adanya. Gambar atau foto bermanfaat dalam hal ini, c) media gambar atau foto dapat mengatasi keterbatasan pengamatan kita. Sel atau penampang daun yang tiding mungkin kita lihat dengan mata telanjang dapat disajikan dengan jelas dalam bentuk gambar atau foto, d) foto dapat memperjelas suatu masalah, dalam bidang apa saja dan untuk tingkat usia berapa saja, sehingga dapat mencegah atau membetulkan kesalahpahaman, e) foto harganya lebih murah dan lebih gambar didapatkan serta digunakan tanpa memelukan peralatan khusus.

Selain kelebihan-kelebihan tersebut, gambar atau foto memiliki kelemahan-kelemahan seperti: a) gambar foto hanya mampu menekankan persepsi indera mata, b) gambar atau foto benda terlalu kompleks dan kurang efektif untuk kegiatan pembelajaran, c) ukurannya yang snagat terbatas untuk kelompok besar.

Dengan media gambar ini, diharapkan siswa dapat lebih membuka wawasannya dan mampu memecahkan permaslahan yang sedang di hadapi dalam pembelajaran, sehingga siswa juga termotivasi untuk belajar berbagi pengetahuan dengan temannya. Dengan menggunakan media ini diharapkan siswa dapat fokus terhadap proses belajar mengajar di dalam kelas.

Adapun tujuan penelitian ini adalah untuk mengetahui berbedaan yang signifikan hasil belajar IPA antara kelompok siswa yang dibelajarkan dengan model pembelajaran Problem Based Learning (PBL) berbantuan media gambar dan kelompok siswa yang tidak menggunakan model pembelajaran Problem Based Learning pada siswa kelas III SD Gugus Kecamatan Sawan Tahun Pelajaran 2017/2018.

\section{METODE}

Penelitian ini merupakan jenis penelitian eksperimen semu dengan rancangan nonequivalent post-test only control group design, rancangan ini dipilih karena eksperimen tidak mungkin mengubah kelas yang ada. Desain non-equivalent post-test only control group design adalah sebagai berikut. 
Tabel 1.

Desain Penelitian Eksperimen

\begin{tabular}{|c|c|c|}
\hline Kelas & Perlakuan & Post-test \\
\hline $\mathrm{E}$ & $\mathrm{X}_{1}$ & $\mathrm{O}_{1}$ \\
\hline $\mathrm{K}$ & - & $\mathrm{O}_{2}$ \\
\hline \multicolumn{3}{|c}{ Sumber: (Agung, 2014) }
\end{tabular}

Berdasarkan tabel diatas, dapat diketahui kelompok eksperimen diberikan perlakuan $\mathrm{X}_{1}$ yaitu dengan menggunakan model pembelajaran Problem Based Learning dan kelompok kontrol tidak diberikan perlakuan yaitu tidak dibelajarkan dengan menggunakan model pembelajaran Problem Based Learning. Populasi dalam penelitian ini adalah seluruh siswa kelas III SD Gugus VI Kecamatan Sawan.Berikut data SD di Gugus VI Kecamatan Sawan.Sekolah Dasar Negeri di Gugus VI Kecamatan Sawan yaitu SDN 1 Krobokan, SDN 1 Sangsit, SDN 7 Sangsit, SDN 4 Sangsit, dan SDN 8 Sangsit.

Jika dari keseluruhan populasi yang ada, kemudian hanya diambil sebagian menjadi wakil populasi tersebut, maka wakil populasi tersebut dinamakan sampel.Jadi sampel merupakan bagian dari populasi yang secara langsung dikenai penelitian. Pengambilan sampel dari populasi menggunakan Teknik group random samplingdengan cara undian dalam menentukan kelas eksperimen dan kontrol dalam penelitian.

Berdasarkan pengundian yang telah dilakukan bahwa kelas III SD N 1 Krobokan yang berjumlah 18 sisiwa dan Kelas III SD N 4 Sangsit berjumlah 23 siswa sebagai sampel.

Hasil group random sampling menentukan kelas yang akan digunakan sebagai kelompok eksperimen yaitu SDN 4 Sangsit dan kelompok control yaitu SDN 1 Kerobokan. Pada saat analisa data dari setiap kelompok diambil skor hasil belajar IPA siswa.Skor-skor tersebut kemudian dianalisis untuk memenuhi teknik analisis data.Informasi mengenai hasil belajar IPA siswa diperoleh melalui nilai UAS dari masing-masing sekolah.

Sebelum dilakukan penentuan sampel penelitian, dilakukan uji kesetaraan pada semua sekolah SD yang ada di Gugus VI Kecamatan Sawan.Data yang digunakan dalam uji kesetaraan adalah nilai ulangan akhir semester (UAS) ganjil mata pelajaran IPA kelas III. Uji kesetaraan ini menggunakan analisis Anava A. Hasil analisis dengan Anava A pada taraf signifikasnsi $5 \%$, diperoleh $F_{\text {hit }}=0,26$ dan $F_{t a b}=2,29$. Jadi $F_{\text {hit }}<F_{\text {tab. }}$ dengan demikian maka HO diterima, dari pernyataan tersebut maka dapat ditarik kesimpulan bahwa nilai UAS IPA keenam sekolah tersebut setara (sama).

Data yang dikumpulkan dalam penelitian ini adalah hasil belajar siswa, dengan menggunakan metode tes yang akan digunakan untuk mengukur skor siswa. Penelitian ini menggunakan tes obyektif (pilihan ganda). Tes obyektif (pilihan ganda ) digunakan pada saat post-test.

Sebelum digunakan untuk penelitian, tes yang telah disusun akan diujicobakan terlebih dahulu. Hal ini dimaksudkan untuk memperoleh gambaran mengenai kelayakan tes tersebut digunakan sebagai instrumen penelitian.kualitas alat ukur hasil belajar pada ranah kognitif ditentukan oleh beberapa faktor antara lain : 1) Uji Validitas, 2) Reliabilitas, 3) Daya Beda Tes, 4) Tingkat Kesukaran.

Validitas isi tes diukur oleh 2 orang ahli yang berkopeten dibidang isi pelajaran IPA. Tes yang digunakan adalah tes pilihan ganda berbentuk dikotomi ( nilai 0 dan 1 ). Jawaban yang benar diberikan skor 1 dan jawaban salah diberikan skor 0 .

Suatu butir tes dinyatakan valid jika $r_{\text {hit }}<r_{\text {tab }}$ dengan taraf signifikansi atau taraf kekeliruan 5\% $\left(r_{\text {hit }}<r_{\text {tab }}\right.$ dengan taraf signifikasi 5\%). Nilai validitas butir yang diperoleh mencerminkan keseluruhan butir tes yang dihasilkan. Berdasarkan hasil pengujian data yang dilakukan terhadap hasil uji coba tes instrumen pengumpulan data yang diinput dari 38 orang siswa di SDN 2 Kaliuntu dan SDN 3 Kaliuntu, menjawab soal sebanyak 35 butir soal dan diperoleh 25 butir soal yang valid.

Untuk menghitung reliabilitas instrumen hasil belajar digunakan rumus Kuder Richardson 20 (KR-20). Berasarkan hasil perhitungan reliabilitas tes hasil belajar 
menggunakan rumus $K R-20$ diperoleh $r_{1.1}=0,902$ itu artinya bahwa soal pilihan ganda pada penelitian ini tergolong sangat tinggi.

Berdasarkan hasil perhitungan diperoleh 25 butir tes yang memenuhi kriteria tes dari 35 butir tes yang diujicobakan. Proses penentuan kelompok atas dan kelompok bawah dilakukan dengan mengurutkan skor setiap siswa dari skor tertinggi sampai yang memperoleh skor terendah. Setelah diurutkan kemudian ditentukan jumlah kelompok atas dengan kelompok bawah, untuk menentukan kedua kelompok tersebut adalah dengan mengalikan jumlah keseluruhan testee dengan $27 \%$.

Tingkat kesukaran peerangkat tes adalah bilangan yang menunjukan rata-rata proporsi testee yang dapat menjawab seluruh (perangkat) tes tersebut. Dari hasil perhitungan dan ujitingkat kesukatan item bahwa butir soal berada pada tingkat mudah sebanyak 8 soal dan sedang sebanyak 17 soal.

Sebelum melakukan uji-t terlebih dahulu melakukan teknik analisis data statistik inferensial yaitu uji normalitas sebaran data dan uji homogenitas varians.Sebelum dilakukan pengujian untuk mendapatkan kesimpulan, maka data yang diperoleh perlu diuji normalitas. Uji normalitas sebaran dilakukan untuk menyajikan bahwa sampel benar-benar berasal dari populasi yang berdistribusi normal.Uji normalitas sebaran data untuk skor hasil belajar IPA siswa digunakan analisis uji Kolmogorov- Smirrnov test dan Shapiro-Wilk test dengan bantuan SPSS.kriteria pengujian yang digunakan adalah data yang memiliki sebaran data normal jika angka signifikansi yang dihasilkan lebih dari 0,05.

Data dari skor awal kedua sampel diuji homogenitasnya untuk menentukan bahwa kedua kelas tersebut memiliki penguasaan yang relatif sama atau homogen, sehingga penelitian dapat dilakukan pada kedua kelas tersebut. Berdasarkan hasil perhitungan pada uji homogenitas, maka kedua sampel tersebut homogen dan pelaksanaan eksperimen dapat dilakukan pada kedua kelas tersebut.

Sebelum dilakukan analisis t-test data harus dalam keadaan berdistribusi normal dan varians dalam kelompok homogen. terkait dengan hal tersebut sebelum menggunaan analisis $t$ test data harus diuji normalitas dan homogenitasnya. Berdasarkan hipotesis penelitian yang telah diajukan pada kajian teori maka dapat dirumuskan hipotesis nol $\left(\mathrm{H}_{0}\right)$ yaitu tidak terdapat perbedaan hasil belajar IPA siswa yang belajar menggunakan model pembelajaran PBL dengan kelompok siswa yang belajar tidak menggunakan model pembelajaran PBL.

\section{HASIL DAN PEMBAHASAN}

Pada bagian ini membahas hasil penelitian dan pembahasan penelitian.Uji prasyarat analisis data dilakukan sebelum melaksanakan uji hipotesis. Terdapat beberapa persyaratan analisis data yang harus dipenuhi, meliputi: 1) uji normalitas, 2) uji homogenitas varians.

Uji normalitas sebaran data dimaksudkan untuk meyakinkan bahwa sampel benarbenar berasal dari populasi yang berdistribusi normal pada dua kelompok data dalam penelitian ini, yaitu (1) hasil belajar IPA pada kelas eksperimen, (2) hasil belajar IPA pada kelas kontrol. Uji normalitas sebaran data dilakukan dengan bantuan SPSS-16.0 for windows uji statistik Kolmogorov-Smirnov pada taraf signifikan 0,05. Uji ini dilakukan terhadap data post-test terhadap kelompok eksperimen dan kelompok kontrol. Apabila nilai signifikansi lebih besar daripada signifikansi (a) maka sampel berasal dari populasi berdistribusi normal.

Normalitas sebaran data diuji dengan teknik Kolmogorov-Smirnov dan Shapiro-Wilk menggunakan bantuan SPSS-16.0 for windows yang diperoleh hasil seperti yang disajikan pada tabel 
Tabel 2.

Hasil Uji Normalitas Sebaran Data dengan Teknik Kolmogorov-Smirnov danShapiro-Wilk dengan Taraf Signifikansi 5\%

\begin{tabular}{|l|c|c|c|c|c|c|}
\hline & \multicolumn{3}{|c|}{ Kolmogorov-Smirnov } & \multicolumn{3}{c|}{ Shapiro-Wilk } \\
\hline & Statistic & Df & Sig. & Statistic & df & Sig. \\
\hline Eksperimen & .082 & 18 & .200 & .978 & 18 & .932 \\
\hline Kontrol & .134 & 18 & .200 & .957 & 18 & .550 \\
\hline
\end{tabular}

Berdasarkan data pada tabel diatas, menunjukkan bahwa statistik Kolmogorov-Smirnov memiliki angka signifikansi lebih besar dari 0,05. Maka dapat disimpulkan semua sebaran data hasil belajar sudah berdistribusi normal.

Uji homogenitas varians antar kelompok bertujuan untuk memeriksa kesamaan varians antar kelompok perlakuan.Dalam penelitian ini, uji homogenitas dilakukan terhadap varians pasangan antar kelompok eksperimen dan kontrol.Uji yang digunakan adalah uji- $\mathrm{F}$ dengan kriteria data homogen jika $F_{\text {hit }}<F_{\text {tab. }}$.

Tabel 3.

Hasil Uji Homogenitas Varians antar Kelompok Eksperimendan Kontrol

\begin{tabular}{|c|c|c|c|}
\hline Data & $F_{\text {hitung }}$ & $F_{\text {tabel }}$ & Kesimpulan \\
\hline $\begin{array}{c}\text { Post-Test Kelompok Eksperimen } \\
\text { dan Kelompok Kontrol }\end{array}$ & 2,00 & 2,13 & Homogen \\
\hline
\end{tabular}

Berdasarkan tabel di atas, diketahui $\mathrm{F}_{\text {hit }}$ hasil kelompok eksperimen dan kontrol adalah 2,00 sedangkan $\mathrm{F}_{\text {tab }}$ pada $\mathrm{db}_{\text {pembilang }}=17, \mathrm{db}_{\text {penyebut }}=22$, dan taraf signifikansi $5 \%$ adalah 2,13. Hal ini berarti, varians data hasil belajar IPA kelompok eksperimen dan kontrol adalah homogen.

Untuk mengetahui pengaruh model pembelajaranProblem Based Learning terhadap hasil belajar IPA siswa, dilakukan pengujian terhadap hipotesis nol $\left(\mathrm{H}_{0}\right)$.

Kriteria pengujian adalah tolak $\mathrm{H}_{0}$ jika $\mathrm{t}_{\text {hit }}>\mathrm{t}_{\mathrm{tab}}$, dimana $\mathrm{t}_{\text {tab }}$ diperoleh dari tabel distribusi $t$ pada taraf signifikansi $5 \%$ dengan derajat kebebasan $\mathrm{db}=\mathrm{n} 1+\mathrm{n} 2-2$. Rangkuman hasil analisis uji-t ditampilkan pada tabel 4. berikut.

Tabel 4.7

Hasil Uji-T

\begin{tabular}{|c|c|c|c|c|c|c|}
\hline Kelompok & $\mathrm{N}$ & $\mathrm{Db}$ & Mean & $s^{2}$ & $t_{\text {hit }}$ & $t_{\text {tab }}$ \\
\hline Eksperimen & 23 & \multirow{2}{*}{39} & 16,52 & 14,52 & \multirow{2}{*}{4,75} & \multirow{2}{*}{2,042} \\
\hline Kontrol & 18 & & 11,77 & 7,24 & & \\
\hline
\end{tabular}

Berdasarkan tabel analisis di atas, dapat diketahuit hit $=4,75$ dan $\mathrm{t}_{\mathrm{tab}}=2,042$ untuk $\mathrm{db}=$ 39 pada taraf signifikansi $5 \%$. Berdasarkan kriteria pengujian, karena $t_{\text {hit }}>t_{\text {tab }}$ maka $H_{0}$ ditolak dan $\mathrm{H}_{1}$ diterima. Artinya, terdapat perbedaanyang signifikan hasil belajar IPA antara kelompok siswa yang belajar menggunakan model pembelajaran Problem Based Learning dengan kelompok siswa yang belajar tidak menggunakan model pembelajaran Problem Based Learning pada siswa kelas III SDGugus VI Kecamatan Sawan.

Hasil analisis data menunjukkan bahwa terdapat perbedaan hasil belajar antara kelompok siswa yang menggunakan model pembelajaran Problem Based Learning berbantuan media gambar dengan siswa yang tidak menggunakan model pembelajaran Problem Based Learning.Tinjauan ini didasarkan pada hasil uji-t dan rata-rata skor hasil belajar siswa. Analisis data menggunakan uji-t, diketahui $t_{\text {hit }}=4,75$ dan $t_{\text {tab }}$ pada taraf signifikansi $5 \%=2,042$. Hasil perhitungan tersebut menunjukkan bahwa $t_{\text {hit }}>t_{\text {tab }}$, sehingga hasil penelitian adalah signifikan.Hal ini berarti, terdapat perbedaan yang signifikan hasil belajar antara kelompok siswa yang menggunakan model pembelajaran Problem Based Learning berbantuan media gambar dengan siswa yang tidak menggunakan model pembelajaran Problem Based Learning.

Berdasarkan rata-rata skor hasil belajar siswa yang menggunakan model pembelajaran PBL adalah 16,52 dan rata-rata skor siswa yang tidak menggunakan model pembelajaran PBL 
adalah 11,77. Hal ini menunjukkan hasil belajar kelompok siswa yang menggunakan model pembelajaran $\mathrm{PBL}$ lebih tinggi dibandingkan dengan kelompok siswa yang tidak menggunakan model pembelajaran PBL. Dapat dikatakan bahwa, model pembelajaran PBL mempengaruhi hasil belajar siswa dikarenakan model PBL memiliki beberapa kelebihan seperti: siswa didorong untuk memiliki kemampuan memecahkan masalah dalam situasi nyata sehingga siswa mampu membangun pengetahuannya melalui aktivitas belajar. Model PBL juga memiliki beberapa kelebihan yang membuat siswa nyaman dalam belajar yaitu pembelajaran berfokus pada masalah atau materi sehhingga beban siswa untuk menghafal menjadi lebih berkurang, dengan PBL siswa mampu melakukan kegiatan diskusi sehingga kesulitan individual dapat diatasi.

Perbedaan hasil belajar IPA tersebut disebabkan oleh hal-hal berikut.Pertama, kelompok siswa yang mengikuti pembelajaran dengan menggunakan model pembelajaran Problem Based Learning diperkenalkan dengan pembelajaran penemuan masalah.Adanya masalah yang disajikan dalam bentuk gambar 2 dimensi membuat siswa termotivasi terlibat dalam pemecahan masalah.Siswa tampak antusias dalam mengikuti dalam memecahkan masalah.Siswa juga memiliki kebebasan dan keleluasaan untuk mengembangkan penngetahuan berdasarkan kehidupan nyata. Dengan demikian, pemahaman siswa akan meningkat sehingga hasil belajar siswa pun menjadi lebih baik.

Kedua tahapan model Problem Based Learning melatih siswa belajar bekerja secara sisetematis dalam artian siswa dibelajarkan untuk dilibatkan dalam pemecahan masalah dengan melakukan diskusi sampai pada melaporkan hasil diskusi pada materi menghemat energi, kenampakan permukaan bumi, dan cuaca untuk meningkatkan hasil belajar IPA siswa. Guru hanya bertugas sebagai fasilitator saja, misalnya dalam materi kenampakan permukaan bumi, siswa diajak mengamati beberapa gambar, kemudian siswa mengaitkan dengan pengalaman masing-masing siswa, bagaimana ciri bukit yang pernah mereka lihat, sehingga siswa di dorong untuk mendefinisikan tugas belajar bersama dengan kelompoknya. Pada tahap selanjutnya siswa mengumpulkan informasi yang sesuai dengan permasalahan, misalnya setelah mereka mengamati gambar dan mengingat pengalaman mengamati bukit, siswa mulai berdiskusi untuk menyusun berupa laporan atau jawaban dari media gambar yang sudah diamati dan berhubungan dengan kenampakan permukaan bumi yang lainnya, misalnya gunung, lembah, sungai, danau dan yang lainnya. Setelah melakukan diskusi dan melaporkan hasil diskusi, guru memberikan refleksi dengan mengajukan beberapa pertanyaan dan setelah itu memberikan evaluasi kepada siswa mengenai materi cuaca pada mata pelajaran IPA.Pada setip langkah pembelajaran, siswa selalu berperan secara aktif sehingga pembelajaran memusatkan perhatian siswa.Hal tersebut juga sesuai dengan hasil penelitian yang dilakukan Wiranata (2017) menyatakan siswa mendapatkan pembelajaran yang bermakna karena permasalahan atau materi yang dibahas dikaitkan dengan lingkungan sekitar siswa.Dengan pembelajaran yang bermakna siswa menjadi lebih memahami materi dan tidak hanya sekedar mengingat ataupun menghafal materi.

Pembelajaran yang menggunakan model pembelajaran Problem Based Learning membuat siswa menjadi aktif dan berani mengajukan pendapat dalam proses pembelajaran. Ingatan siswa dapat bertahan lama dikarenakan siswa diberikan permasalahan berdasarkan kehidupan nyata. Dapat dilihat dari pembelajaran model Problem Based Learning berbantuan media gambar yang menekankan keterlibatan siswa dalam menemukan sendiri pengetahuannya sehingga pada saat akhir penelitian siswa diberikan test dan siswa masih terbayang dengan permasalahan yang dipelajari sebelumnya dengan bantuan media gambar. Siswa juga mampu aktif dalam diskusi kelompok dan guru hanya sebagai fasilitator dan motivator dalam pembelajaran.

Model pembelajaran Problem Based Learning merupakan suatu pembelajaran yang berpusat pada siswa, mengembangkan pembelajaran aktif, keterampilan memecahkan masalah dan didasarkan pada pemahaman serta pemecahan masalah (Kusuma, 2014).Model pembelajaran ini menjadikan siswa sebagai pusat pembelajar sehingga siswa mampu menjadi aktif daam memecahkan suatu permasalahan yang telah diberikan oleh guru. Adanya bantuan media gambar menyebabkan siswa tertarik dan antusias untuk mengikuti proses pembelajaran. 
Hasil penelitian ini mendukung penelitian sebelumnya yang dilakukan oleh Sastrawan (2014) yang menyatakan bahwa model pembelajaran PBL berbantuan media visual animasi lebih unggul dibandingkan dengan model pembelajaran konvensional terhadap hasil belajar IPA. Penelitian ini mengemukakan bahwa siswa yang mengikuti model pembelajaran Problem based learning mempunyai penglaman belajar yang langsung dari permasalahan yang bersifat nyata yang diberikan oleh guru.

Model pembelajaran Problem Based Learning dapat mendorong siswa mempunyai keinginan untuk belajar mandiri contohnya pada saat kelompok dibentuk secara heterogen, siswa yang memiliki kemampuan lebih tinggi semangat membantu siswa yang memiliki kemampuan lebih rendah dalam hal mengingat materi dan memecahkan permasalahan yang diberikan oleh guru. Di dalam kelompokpun mereka aktif berinteraksi dan berusaha menyelesaikan masalah yang nyata sehingga pembelajaran dapat berjalan dengan maksimal.

Dengan demikian hasil penelitian ini membuktikan bahwa model pembelajaran Problem Based Learning memberikan pengaruh terhadap hasil belajar siswa.Tentu saja dalam hal ini hasil belajar siswa meningkat.Hal ini dapat dilihat dari pembelajaran Problem Based Learning lebih banyak menekankan keterlibatan siswa dalam menemukan sendiri pengetahuannya dengan melakukan kegiatan diskusi kelompok sedangkan guru hanya bertugas sebagai fasilitator dan motivator dalam pembelajaran.

Hambatan yang ditemukan ketika dilakukan penelitian pada kelas eksperimen tidak terlalu berarti. Hanya ada beberapa hambatan kecil seperti masih terdapat beberapa siswa yang suka bercanda dan kurang fokus dalam mengikuti proses pembelajaran tetapi hal tersebut sudah dapat ditanggulangi oleh guru dengan memberikan perhatian lebih kepada siswa yang bersangkutan. Sementara hambatan di kelas kontrol lebih banyak ditemukan.Hambatan-hambatan tersebut adalah ditemukan siswa yang kurang bisa dalam membaca sehingga membutuhkan perhatian banyak dari guru, ditemukan siswa yang bermain sehingga kurang memperhatikan guru saat menjelaskan materi. Selain itu terdapat pula beberapa siswa yang bercanda dan mengajak temannya mengobrol pada saat jam pembelajaran berlangsung.

\section{SIMPULAN DAN SARAN}

Berdasarkan hasil pengujian hipotesis dan pembahasan, maka temuan dalam penelitian ini menyatakan bahwa terdapat perbedaan yang signifikan hasil belajar IPA siswa yang menggunakan model pembelajaran Problem Based Learning berbantuan media gambar dan kelompok siswa yang tidak menggunakan model pembelajaran Problem Based Learning. Hasil analisis menunjukkan bahwa $t_{\text {hitung }}=4,75$ dengan $t_{\text {tabel }}=2,042$ hal ini berarti nilai $t_{\text {hitung }}>t_{\text {tabel }}$. Hal ini menunjukan hasil belajar IPA siswa yang menggunakan model pembelajaran Problem Based Learning berbantuan media gambar lebih tinggi dibandingkan hasil belajar IPA siswa yang tidak menggunakan model pembelajaran Problem Based Learning.

Maka dapat disimpulkan bahwa pembelajaran dengan model pembelajaran Problem Based Learning berbantuan media gambar berpengaruh positif terhadap hasil belajar IPA siswa kelas III Semester Genap di SD Gugus VI Kecamatan Sawan Tahun Pelajaran 2017/2018.

Saran untuk siswa diharapkan selalu terlibat secara aktif dalam mengikuti proses pembelajaran, sehingga nantinya mendapatkan pengetahuan baru yang ditemukan sendiri sehingga hasil belajar dapat meningkat.

Bagi guru di dalam menyampaikan materi pelajaran hendaknya berinovasi dalam memilih model dan media yang dapat mengatasi karakter siswa yang berbeda-beda.

Bagi kepala sekolah, terutama di sekolah dasar hendaknya menjadikan model PBL sebagai model pembelajaran yang dapat diterapkan dalam pembelajara di sekolah dasar, dan dapat dijadikan sebagai aturan guru dalam mengajar di dalam kelas.

Bagi peneliti lain yang akan melakukan penelitian lebih lanjut tentang model pembelajaran PBL berbantuan media gambar dalam bidang pelajaran IImu Pengetahuan Alam maupun pelajaran yang lain agar memperhatikan kendala yang dialami di dalam penelitian ini, 
agar menjadi bahan pertimbangan untuk perbaikan dan penyempurnaan penelitian yang akan dilaksanakan.

\section{DAFTAR RUJUKAN}

Agung. 2014. Metodologi Penelitian. Malang: Aditya Media Publishing.

Hanafiah, Nanang., dan Suhana Cucu. 2009. Konsep Strategi Pembelajaran.Bandung: Refika Aditama.

Kurnia, Ingridwati. 2007. Perkembangan Belajar Peserta Didik. Jakarta: Departemen Pendidikan Nasional.

Kurniasih, Imas dan Sani Berlin, 2016.Ragam Pengembangan Model Pembelajaran. Jakarta: Kata Pena.

Kusuma. 2014. Pengaruh Model Pembelajaran Problem-Based Learning Tehadap Hasil Belajar IpaPasa Siswa kelas V Semester Ganjil di Gugus XIV SD Kecamatan Buleleng Kabupaten Buleleng Tahun pelajaran 2013/2014. Jurnal Mimbar PGSD. Vol: 2 No: 1. PGSD Undiksha. (hlm 1-10).

Laksana, Laba Ngurah. 2016. Miskonsepsi Dalam Materi Ipa Sekolah Dasar. Jurnal Pendidikan Indonesia, Vol.5. No. 2.Program Studi Pendidikan Guru Sekolah Dasar STKIP Citra Bakti. ISSN: 2303-288X. (hlm 873-882).

Marhaeni. 2013. Landasan dan Inovasi Pembelajaran. Singaraja: Universitas Pendidikan Ganesha.

Musfiqon.2012. Pengembangan Media dan Sumber Pembelajaran.Jakarta:Prestasi Pustaka Raya.

Riastini, Putu Nanci. 2016. Pembelajaran IPA SD. Singaraja: Universitas Pendidian Ganesha.

Ruhimat, Toto. 2013. Tim Pengembang MKDP Kurikulum dan Pembelajaran. Jakarta: Rajawali Pers

Samatowa, Usman. 2010. Pembelajaran IPA di Sekolah Dasar. Jakarta Barat: Indeks.

Sastrawan.2014. Pengaruh Model Pembelajaran PBL Berbantuan Media Visual Animasi Terhadap Hasil Belajar IPA Siswa Kelas V SD Gugus II Tampaksiring Gianyar. Ejournal PGSD Vol:2 No: 1. PGSD Undiksha. (hlm 1-11).

Shoimin, Aris. 2014. 68 Model Pembelajaran Inovatif dalam Kurikulum 2013. Yogyakarta: ARRUZZ MEDIA.

Sukariyasa, Eta. 2014. Pengaruh Model Problem Based Learning Berbantuan Media Gambar Terhadap Hasil Belajar IPA Siswa Kelas V di Gugus Belantih.E-Journal MIMBAR PGSD.Vol:2 No:1. (hIm 1-10).

Susanti, dkk. 2013. Pengaruh Penerapan Model Pembelajaran Mind Mapping Berbantuan Media Gambar Terhadap Hasil Belajar IImu pengetahuan Sosial Siswa Kelas IV SD Gugus IV Kecmatan Sukawati. E-journal PGSD. (hlm 1-10). 
Susanto, Ahmad. 2013. Teori Belajar dan Pembelajaran. Jakarta: Kencana Prenadamedia Group.

Undang-undang Republik Indonesia No. 20 Tahun 2003 tentang Sitem Pendidikan Nasional. 2003. Jakarta: Presiden Republik Indonesia.

Wuryandani. 2011. Pembelajaran PKN di Sekolah dasar. Yogyakarta: Nuha Litera.

Yamin, Moh. 2014. Teori dan Metode Pembelajaran. Jawa Timur: Madani (Kelompok Instrans Publishing). 